\title{
Nog steeds geslote eredienste? \\ Deel 2
}

\section{W C van Wyk \\ Hervormde Teologiese Opleiding}

Tydelik-deeltydse dosent: Universitcit van Pretoria

\begin{abstract}
Should church services still be closed? Part 2

This paper - in two parts - deals with the question of whether the Nederduitsch Hervormde Church should continue being a church for white persons only. The auther argues that this practice is not according to biblical teachings and, at the same time, that it will be unwise to continue it under the future sociopolitical circumstances in South Africa. He therefore calls on the Nederduitsch Hervormde Church to abandon this practice as it will bring the church into conflict with its own theological tradition.
\end{abstract}

\section{GESLOTE EREDIENSTE: 'N ONHOUDBARE PRAKTYK EN 'N NIE- MEER VERDEDIGBARE TEORIE}

\subsection{Die botsings tussen ideale en werklikhede}

Die standpunt word dikwels gestel (kyk bv Steenkamp 1989:35) dat daar geen rede vir die Hervormde Kerk bestaan om van sy tradisionele standpunt oor erediensbywoning af te wyk nie. Die argument is die volgende: Die kerk se standpunt is nie uit die gees van 'n bepaalde tyd gebore nie. Dit is nie 'n standpunt wat by veranderende omstandighede hoef aan te pas nie, aangesien hierdie standpunt die 'Afrikaner se Calvinistiese lewens- en wêreldbeskouing' weergee. Hierdie standpunt (al le die oorsprong daarvan by die volk) is 'n onveranderlike norm, aangesien die volk die kerk was en die stem van die volk daarom gelyk is aan die stem van die kerk (van God?).

Ten spyte daarvan dat hierdie standpunt met Artikel 29 van die NGB en met die gedagte van die Calvinisme dat 'n kerk hom voortdurend moet hervorm, in stryd is, is daar tog soms (bv deur die Herderlike Skrywe van 1973) gemeen dat Artikel III 'n onveranderbare beginsel is. 
Teenoor die standpunt dat Artikel III 'n onveranderlike beginsel is, word die standpunt ook binne die kerk gestel dat Artikel III, soos geslote eredienste, soos geslote volkskerke, 'n veranderbare beleid is. Die volgende teoloë het in hierdie verband belangrike rigting gegee: Pont ([1959] 1978:108-110) het die kerk in 1959 daaraan herinner, dat die gedagte van aparte kerke en aparte eredienste nog altyd net 'n werksverdeling is wat op praktiese oorwegings en nie op prinsipieel-teologiese gronde berus nie. Verwysende na Johannes 17:21 sê hy dat die kerk altyd die eenheid moet soek en bewaar omdat ons almal lede van dieselfde liggaam is. Die implikasies hiervan is, dat die kerk aparte eredienste nie as 'n beginselsaak mag beskou nie, dit nie rigied mag toepas nie en selfs die hele reêling in heroorweging moet neem wanneer dit ' $n$ belemmering word in die uitlewing van die opdrag tot eenheid. Dreyer ([1962] 1978:74) het weer in 1962 daarop gewys, dat die Hervormde Kerk nie die belydenis en Bybelse eksegese met sy kerklike beleid vermeng nie. Hy probeer daarom nie om sy rassebeleid en sy kerkbeleid met teksverse te begrond nie. Verder maak hy ook nie daarop aanspraak, dat hy 'n leerstuk oor rasse probeer aanbied nie. Al wat hy wil sê, is dat hy meen dat hy 'n prakties werkbare beleid het wat goeie resultate in ons gekompliseerde situasie kan oplewer. Werk hierdie beleid nie, sal hy aan ' $n$ ander beleid moet dink.

In 1985 (Van Wyk 1985:34-37) stel die ondersoekkommissie na Artikel III dit weer eens duidelik, dat Artikel III 'n beleid is en daarom oop is vir wysiging en aanpassing. Tog meen hulle op grond van 'n uitspraak van die Moderamen in Januarie 1974, dat Artikel III tog ook wel 'n beginselsaak is. Dit is nou wel nie 'n filosofiese beginsel nie, maar tog 'n geloofsbeginsel. Daarmee wil hulle sê, dat Artikel III wel Skriftuurlik verantwoordbaar is, aangesien dit binne die breë raamwerk van die Skrifverkondiging oor volkereverskeidenheid, werksverdeling, volksidentiteit, geregtigheid, liefde en orde verdedigbaar is.

Of ' $n$ mens Artikel III as 'n onveranderbare beginsel wil sien of nie, die feit bly staan dat die werklikheid, die historiese noodwendighede en die sosiologiese gegewendhede die kerk dwing om by die wêreld aan te pas. Die Voortrekkerkerk en die kerk binne die ZAR het ook al met hierdie onaangename stuk lewenswerklikheid te make gekry. Daar kan na twee voorbeelde verwys word: (a) Die Voortrekkers wou ten alle koste vry en onafhanklik van die Kaapse Kerk funksioneer. Hulle wou onder geen omstandighede van Kaapse predikante gebruik maak nie, aangesien hulle 'n gevaar vir die Afrikaner se godsdienstige- en daarom ook vir sy politieke vryheid ingehou het. Hierdie gemeenskaplike vryheidstrewe van 'volk' en 'kerk' het egter gou met die harde werklikhede in botsing gekom. Die 'kerk' kon eenvoudig nie geheel en al afsonderlik van die Kaapse kerk funksioneer nie. Daar moes in 1852 toegestem word dat predikante uit die Kaap hulle mag bedien. Die 
'kerk' moes sy beginsel; 'vryheid en onafhanklikheid ten alle koste' opoffer sodat die evangelie sy voortgang kon kry. Daar was wel hewige protes van die volk se kant af by die owerheid oor die beslissing wat op kerklike terrein geval het (Pont 1969:206), maar die feit bly staan dat hierdie ideaal van vryheid en die beginsel van onafhanklikheid, minstens kerklik, baie gou deur die werklikhede ingehaal is. (b) Die teokratiese ideale van die volk en kerk was ook nie teen die gang van die geskiedenis opgewasse nie. Hoe lofwaardig hierdie ideaal ookal mag wees, die feit bly dat die teokrasie deur die demokrasie vervang is. Na die oorlog van 1899-1902 moes die Afrikaners die Engelse se demokratiese staatstruktuur en hulle liberalistiese lewensopvatting ten opsigte van die openbare lewe duld en aanvaar (Pont 1991:797). Hulle moes aanvaar, hoe vreemd en onaanvaarbaar dit ookal mag gewees het, dat die volksowerheid met 'n party-owerheid vervang is (Botes 1991:803). Feitlik al wat van hierdie ideaal oorgebly het, is Artikel IX van die Kerkwet, wat oor 'die voortdurende evangelisering en hervorming van die volkslewe' praat.

Die kerk moet in die tyd bestaan. Hy kan nie 'n klooster van 'n vorige epog wees en dan nog hoop dat hy sal voortbestaan nie. Hoe vry die kerk ookal teenoor die wêreld en in die wereld wil en moet wees, hy kan nie die groot wêreldveranderende kragte ontkom nie. Net so min as wat die kerk met die teologiese verdediging van slawehandel kon voortgaan, net so min sal ons kerk met die teologiese verdediging van Artikel III en geslote eredienste kan voortgaan. Die werklikhede het ons ingehaal.

Die Algemene Kommissie het hierdie dilemma in die verlede deeglik begryp en het om hierdie rede by die tydsomstandighede aangepas. Te midde van druk uit alle oorde, aan die een kant die druk van die progressiewe magte en aan die ander kant die druk van die konserwatiewe magte, het die Kommissie deur die loop van die laaste dekades, dan hier toegegee en dan daar geswig, dan hier weerstaan en dan daar saambeweeg. Om hierdie rede lyk die kaart van besluitnemings in hierdie verband soos wat dit lyk. In 1858 is die eredienste geslote. In 1963 is die eredienste oop. In 1973 is die eredienste geslote. In 1986 is die eredienste byna oop. In 1992 is net besondere eredienste oop.

Diegene wat teologies nie met die werklikhede van ons tyd vrede kan maak nie, kan en wil nie met die feit vrede maak dat die spesifieke teokrctiese ideaal van die Voortrekkers nie in Suid-Afrika geslaag het nie. Omgekeerd kom dit daarop neer dat teokratiese ideale bokant die geskiedenis verhewe is. Dit is eenvoudig nie waar nie. Van 't Spijker (1990:161-162) het juis aan die hand van Calvyn se ekklesiologie aangedui, dat hy wel 'n kerk in Genève kon agterlaat, maar ongelukkig nie 'n Christelik-teokratiese staatstad nie. Hiermee word nie gesê dat die probleem by die teokrasie lê nie, maar wel by die veranderende en verganklike werklikheid. Wolf- 
hart Pannenberg (1981 en 1986) het juis in die onlangse verlede as Lutheraan daarop gewys, dat die Calvinistiese teokrasieteorie waarskynlik vir vandag die mees bruikbare politieke teorie is wat die Christendom kon oplewer.

\subsection{Gelykstelling}

By punt 2.1.1.3. is beskryf wat die kerk onder gelykstelling en nie-gelykstelling verstaan. Ek glo dat 'n mens nie net begrip, maar ook respek vir die kerk se tradisionele standpunt moet hê. Ek is oortuig van die naïewe opregtheid en verantwoordelikheidsin van ons voorouers. Ten spyte van die respek en agting wat ons teenoor ons voorgeslagte mag openbaar, sal ons nie daaraan kan ontkom dat hierdie aspek van Artikel III en ons volkskerkteologie, deur die geskiedenis ingehaal is nie. Die volgende voorspelling van Wolmarans in 1953 ([1953] 1978a:25) aangaande die einde van die ongelykheid het waar geword, maar die droom oor hoe dit gehanteer moet word het nie gerealiseer nie:

En net soos enige voogdyskap moet uitloop op 'n gelykheid van die onderhorige met die voog, net so moes die Afrikaner dit ook voorsien het, dat daar 'n dag sou kom...waarop die opvoedingswerk deur die Blanke tot so 'n mate volbring sou wees en die Nie-Blanke soveel verantwoordelikheidsbesef sou ontwikkel het, dat hy gelykheid met die voog kan verlang. Maar soos wat elke kind, as hy volgroei is, sy gelykheid met sy natuurlike voog kry, nie op dieselfde terrein en in dieselfde huis nie, maar in sy eie, apart van die voog, net so sou die nie-blanke volksgroepe gelykheid met die blanke voog kon kry, vir sover as wat hulle dit kan waardeer en uitleef alleen apart en afgesonder van die blanke gemeenskap....

(Wolmarans [1953] 1978a:25)

As gevolg van 'n statiese werklikheidsverstaan het die Afrikaner hom met die gang van die geskiedenis misgis. Hy het nie voorsien dat die basiese gestruktureerdheid van die wèreld sou kon verander nie. Dat die volkerepatroon van ons land sou verander, het nie in die wildste drome van die Afrikaner bestaan nie. Hierdie 'ontologiese' werklikheidsverstaan waarin 'volke' as aparte konstanthede onveranderd voortbestaan, is deur die geskiedenis as 'n misgissing uitgewys. Die vraag is net: Waarmee presies het ons kerk hom misgis? Die kerk het hom met die groot epogveranderende idees en kragte misgis. Die kerk het hom met die rykwydte van die werkingsgeskiedenis van die Europese rewolusies misgis. Ons kerk het nie gedink, dat dít wat in Europa in die 19e eeu plaasgevind het, na Afrika sou oorspoel nie. Ons kerk is deur sy statiese visie van die werklikheid mislei en het nie besef dat die werklikheid ten diepste geskiedenis (kyk veral Pannenberg 1983: 472-517) is en 
daarom voortdurend aan die verander is nie. Om hierdie rede het ons kerk dit nie voorsien dat die vryheidsvisie van die Franse rewolusie die swartman van Afrika sou imponeer nie. Hy het ook nie ingesien, dat die maatskaplike en politieke outoriteitspatrone deur hierdie vryheidsvisie onherroeplik verander sou word nie.

Jürgen Moltmann (1988:11-14) wys daarop dat die vryheidsvisie van die Franse rewolusie op die ideale van 'vryheid, gelykheid en broedersap' neergekom het. Die Franse bevolking wou die oud-Europese klerikale en feodale standesamelewing afbreek, aangesien hulle in hierdie samelewingsorde die rede vir hulle armoede en ellende gesien het. In die plek van hierdie orde van ongelykheid, het die nuwe orde van die egalitêre prestasiemaatskappy gekom. Nie meer jou afkoms nie, maar jou

prestasie bepaal nou jou waarde as mens en jou posisie in die samelewing. Die soewereiniteit en absolute heerkappy van die vors is dienooreenkomstig met die soewereiniteit en die selfheerskappy van die volk vervang. In die plek van die magstaat het die demokratiese staat sy verskyning gemaak. Die onderdane is tot vrye burgers verhef. In 1803 , met die sekularisering van kerklike eiendommme, het die konfessionele staat ook vir 'n neutrale of sekulêre staat plek gemaak. Die konsekwensie hiervan was, dat godsdiens tot 'n private saak verlaag is en dat die kerklike invloed op die maatskaplik-politieke ontwikkelinge drasties afgeneem het.

Die skep van 'n nuwe burgerlike wêreld het hand aan hand met die skep van die industriële arbeidswêreld gegaan. Die industriële rewolusie het enorme veranderinge in die menslike leefwerreld te weeg gebring. Verstedeliking het veroorsaak dat mense tot 'n groot mate verlaag is tot produsente en konsumente. Die gevolg was dat die tadisionele identiteitskenmerke soos godsdiens, nasionaliteit, kultuur en geslag grootliks verdwyn het. Die mens moes van toe af sy identiteit grootliks as ekonomiese wese skep en ontdek. Die vryheidstryd het daarom ook vanaf godsdiens- en volksoorloë na die ekonomiese stryd van die werkersklasse verskuif. Die historiese ontwikkeling van die Westerse samelewing het dus as naelstring die strewe na vryheid, gelykheid en broederskap en as baarmoeder die ontwikkeling van die idee van menseregte.

Om ons eie agtergehaalde situasie nog beter te verstaan, sal dit goed wees om kortliks ook na die triomferende vryheidsidee binne die burgerlike wêreld te verwys. Die 19 e eeu kan met reg die eeu van die vryheid genoem word. Vanuit die Duitse Idealisme (kyk Van Wyk 1990:5-6) het die gedagte gegroei dat die mens vry is om sy eie lot te bepaal. Hy kan en hy mag sy eie toekoms uitwerk. Die noodlot en die magte (God ingesluit) hoef nie sy lewe te beheer nie. Hyself kan en behoort sy eie heil uit te werk. Met hierdie vryheidsbegrip in die hand, het die mens homself as die subjek van die geskiedenis begin sien. Hy het verplig gevoel om vir sy eie toekoms verantwoordelikheid te neem. Dit het 'n radikale oriëntasieverandering 
ten opsigte van mentaliteit teweeggebring. Die oriëntering van die lewe aan die verlede en die herkoms het plek gemaak vir 'n oriëntasie van die lewe aan die beplanning van die toekoms. So moes die tradisie vir die onbekende nuwe en die mite vir die hoop plek maak. Teologies was dit daarom verstaanbaar dat die gees van die Messianisme (Joachim van Fiore: kyk by Moltmann 1980:220-229) hoogty kan vier met die uiteindelike wens 'om die Ryk van God te realiseer' soos wat Friedrich Schlegel dit gestel het (kyk vir volledigheid Moltmann 1977:210-279).

Die gees van die Franse rewolusie en alles wat daarmee saamhang en daaruit voortgevloei het, het ook oor Afrika gespoel. Die rewolusie van emansipasie, die stryd teen onderdanigheid en die passie van gelykwaardigheid het Art 9 van die grondwet van die ZAR en Artikel III van die Kerkwet nie net ingehaal nie, maar alreeds ver verbygegaan. Die ekonomiese werklikhede in ons land, het die idee en ideaal van aparte gelykhede van die Voortrekkers laat verkrummel ${ }^{1}$.

Die ekonomie as die mees bepalende wêreldlike mag van die $20 \mathrm{e} \mathrm{eeu,} \mathrm{het} \mathrm{trou-}$ ens 'n nog radikaler verandering in die lewenswerklikheid teweeggebring wat ons teologie nog ingrypender aan die keel skud. Die ekonomie het nie noodwendig 'volke' as verskynsel laat verdwyn nie, maar dit aan geweldige relativerings- en veranderingsprosesse onderwerp. Die 'volk' (Gemeinschaft) moes grootliks vir die 'maatskappy' (Gesellschaft) as kulturele lewensruimte plek maak (Tönnies 1988).

Hierdie veranderinge het ook onherroeplik deel van Suid-Afrika geword. Niemand sal beweer dat volke' verdwyn het nie, maar niemand sal kan ontken dat die verskillende 'volke' deel van 'n Suid-Afrikaanse maatskappy geword het nie. Niemand sal kan ontken dat volksgrense in Suid-Afrika aan die verskuif en selfs aan die verdwyn is nie. Indien dit waar sou wees, sal die kerk sy apostolaatsoortuiging dat dit die beste werkswyse is om aan 'volke' die evangelie te verkondig (Van Wyk 1991:777), ernstig onder heroorweging moet bring, met die konsekwensie dat Artikel III en geslote eredienste ook heroorweeg sal moet word.

Dit beteken egter nie dat die kerk vreeslike veranderinge in sy bedieningspatroon hoef aan te bring nie. Wêreldwyd word dit oor en oor bewys dat mense hulle godsdiens binne hulle eie kultuurverband wil uitlewe. Volkskerke as kultuurkerke bly die mees normale wyse van kerkwees. Om hierdie rede sal daar, na die oopstelling van die eredienste, nie 'n dramatiese verandering in ons kerklike praktyk intree nie. Trouens, bitter min sal verander. Hiervan is die Nederduits Gereformeerde Kerk 'n bewys'.

In die lig van alles wat hierbo aangevoer is, sal ons ons eie vryheidsideaal opnuut vanuit die Skrif moet herformuleer om in die veranderende wêreld weer vryheid te kan ontdek. 


\subsection{Vryheid}

Dit is nie ongewoon of eienaardig, dat die Hervormde Kerk se teologie ten diepste vryheidsteologie is nie. Wat ons vandag teologies omgewe, is niks anders as ' $n$ worsteling met die vryheid nie. Die jongste Europese teologie is juis ' $n$ poging om die geloof in God vanuit die menslike vryheid te regverdig (kyk veral Pannenberg 1978a). Vanuit sy teologiese paradigma sê Jürgen Moltmann (1988:32) byvoorbeeld:

Theologie in der Neuzeit wird notwendig eine Theologie der Freiheit sein. Die moderne Welt ist aus Befreiungsbewegungen entstanden und ist weiter in solchen Bewegungen begriffen...Will die christliche Theologie den modernen Atheismus überwinden, dann muß sie zuerst seinen Ansto $ß$ überwinden und beweisen, daß der biblische Gott des Exodus des Volkes und der Auferstehung Christi die Freiheit des Menschen nicht behindert, sondern viel mehr begründet, bewahrt und verteidigt. Ein Christentum, das auf diesen biblischen Freiheitstradition gründete, würde tatsächlich zur 'Religion der Freiheit' (Hegel).

(Moltmann 1988:32)

Jüngel (1978:16) ondersteun hom hierin as hy sê: 'Wenn die gegenwärtige Theologie überhaupt eine thematische Mitte hat, dann ist das die christliche Freiheit'. Hierdie uitsprake is ook nie net kenmerkend van die na-Barthiaanse teologie nie, maar ook van Barth se eie teologie. Trutz Rendtorff (1986) verstaan byvoorbeeld die vryheidsbegrip as die plekbepaling van Barth se Kirchliche Dogmatik.

Wat ons egter duidelik moet besef, is dat ons vryheidsbegrip soos wat dit in Artikel III geformuleer en in terme van geslote eredienste uitgeleef word, na alle waarskynlikheid histories agtergehaal, teologies duidelik onverdedigbaar, in ons dag moreel bedenklik en miskien polities irrelevant is. Ons sal daarom vroegtydig ' $n$ nuwe vryheidsbegrip moet begin ontwikkel wat Bybels-Reformatories begrond, kerklik verantwoordbaar, moreel verdedigbaar en polities relevant sal wees.

\subsection{Die vryheid van die teologie teenoor die politiek}

Soos reeds gestel in 2.1.1.3. is die fokuspunt van my kritiek op ons teologiese vryheidstradisie, die prysgawe van die vryheid van ons teologie. Ten spyte van sterk oortuigings binne ons kerk (vgl o a Van Wyk 1991:773) dat die kerk nog nooit iets van sy kerkwees as gevolg van sy noue verbondenheid met die volk prysgegee het nie, bewys ons kerklike verlede die teendeel. Daar is in die 19e eeu toegelaat dat die staat en die volk aan die kerk en die teologie voorwaardes stel ten opsigte van hulle taakvervulling, selfverstaan en gehoorsaamheid aan die Skrif. Die kerk kon 
tot vandag toe nog nie, ten spyte van ernstige oproepe (kyk Kerk en Wêreld 2000 1985:4), aan hierdie beperkinge ontsnap nie. Dit is geheel en al onaanvaarbaar. Bloot om hierdie rede moet daar toegesien word, dat daar by die herskrywing van die Kerkwet, nie net aan kerkregtelike aspekte nie, maar ook aan dogmatiese sake aandag gegee word, ten einde te verseker dat kerk en teologie in die toekoms in vryheid hulle verantwoordelikhede kan nakom.

Die teologie het met vryheid te make, aangesien dit met God, die vrye God, te make het (Jüngel 1980:12). Die saaklikheid van die teologie verseker die vryheid van die teologie. Die saak van die teologie is nou nie God self nie (Pannenberg 1973:299-348; 1988:1-18), maar die waarwording (Ereignis) van die Woord van God. Op die vraag waar - by watter plek - word die Woord van God waar, kan daar net een antwoord wees, naamlik in die kerk. Vir Jüngel (1980:17) het dít vir kerk en teologie die volgende konsekwensie:

$\mathrm{Da}$ die Theologie ihren existentiellen Ort in der Gemeinde findet, bedeutet also, daß sie sich den Interessen der Kirche in keiner Hinsicht fügen kann, sondern umgekehrt die Gemeinde in jeder Hinsicht theologisch interessieren muß.

(Jüngel 1980:17)

Die vryheid van die teoloog kom daarom daarop neer dat hy sy reg opneem om uitsluitlik teoloog te wees. Prysgawe van teologiese en kerklike vryheid vind plaas, waar politieke strewes die onderwerp van die teologie word. Dit sal nie ontken kan word dat dit tydens die Algemene Kerkvergadering van 1853 (kyk weer punt 2.1.1.2) en met die opname van Art 9 van die grondwet van die ZAR in die Kerkwet, tot 'n groot mate in ons kerk gebeur het nie.

'n Mens moet egter versigtig wees om nie te vinnig en te hard te oordeel nie. Alle teologie is tydelik en wêreldlik. Dit is ingebed in in die tyd, omstandighede en moontlikhede van 'n bepaalde epog. Wie is ons om 'n oordeel oor die geloofsgehoorsaamheid van ons vadere uit te spreek? Ons moet egter seker maak dat ons teologie 'n saakgebonde poging word en dit bly. Die saak, of die eintlike onderwerp waaroor dit in ons kerk moet gaan, het Luther soos volg geformuleer:

Die kenmerkende onderwerp van die teologie is die mens, wat aan die sonde skuldig en [daarom] verworpe is en God, wat die sondige mens regverdig en red. Wat buite hierdie onderwerp in die teologie nagevors of ter sprake gebring mag word, is dwaling en gif.

( $W A$ 40/II, 328, 17-20; my vertaling) 


\subsubsection{Godsdienstige vryheid}

Die Hervormde Kerk het godsdienstige vryheid in die verlede as die rugkant van sy volk se politieke vryheid gesien. Die geslotenheid, afgesonderdheid en na binne gerigtheid van die kerk was die waarborg vir die volk se vryheid. Godsdienstige vryheid is as die geestelike dimensie van die eintlike vryheid - die politieke vryheid beskou. Die godsdienstige vryheid - die binne-kulturele-gemeenskapservaring (Van Wyk 1985) - moes die skut teen politieke onvryheid - 'n multikulturele magsproses - wees.

Die kritiese vraag wat beantwoord moet word, is of hierdie verstaan van godsdienstige vryheid, as Bybels-Reformatoriese vryheid verdedig kan word en of dit verder enige sin het om die kerk aan hierdie vryheidsbegrip gebonde te hou? Vanuit die beantwoording van hierdie vraag, sal dit ook dan duidelik word in hoeverre die kerk by 'n bepaalde opvatting van politieke vryheid betrokke mag raak al dan nie.

Die Reformasie was niks anders as 'n groot vryheidsbeweging nie. Die Reformatoriese teologie het mense nie alleen van die godsdienstige onvryhede van die pous bevry nie, maar hulle ook bevry uit die daarmee samehangende sosiale en ekonomiese strukture (Hamm 1983:50). Om hierdie rede meen Trutz Rendtorff (1978) met reg dat die ganse moderne geskiedenis, sy oorprong in die Reformasie het. Om in voeling te kom met die werkingsgeskiedenis van die Reformasie, sal dit ons goed doen om terug te gaan na van die basiese uitgangpunte van die Reformatoriese vryheidsverstaan.

Binne die Reformatoriese tradisie het ons 'n klassieke tese van Martin Luther (1520) oor die Christelike vryheid:

'n Christenmens is 'n vrye heer oor alle dinge en niemand se onderdaan nie. ' $n$ Christenmens is 'n diensbare kneg van alle dinge en elkeen se onderdaan.

(WA 7, 21; my vertaling)

Luther het hierdie tese opgestel op grond van 1 Kor 9:19: Hoewel ek vry is en van niemand afhanklik nie, het ek my aan almal diensbaar gestel om soveel mense as moontlik vir Christus te wen (NAV; my beklemtoning); en Romeine 13:8: Julle moet niemand iets verskuldig wees nie, behalwe om mekaar lief te hê. Wie sy medemens liefhet, voer die hele wet van God uit (NAV; my beklemtoning). Om hierdie teenstrydige uitprake te verstaan, moet mens volgens Luther dit in gedagte hou, dat die Christenmens iemand met twee nature is. Hy is 'n geestelike en 'n liggaamlike wese; ' $n$ innerlike en 'n uiterlike mens. Die geestelike en innerlike mens is vroom en vry. Uiterlike dinge kan hom nie vroom en vry maak nie. Dit is slegs die Woord en die geloof wat dit kan vermag. Deur die verkondiging van die Woord hoor ons 
van die genade van God vir ons as sondaarmense. Ons word vrye mense deur die geloof; deur God reg te gee. 'n Menskom tot geloof slegs dan, wanneer die vryheid vir ons reg uitgelê word. Ons word nie vry deur enige werke van die wet nie. Goeie werke, van watter aard ookal, maak nie vry nie. Vryheid is dus, volgens Luther, 'n saak wat alleen met geloof en niks met werke te make het nie. Wie egter nie aan Chritus glo nie, is 'n kneg van alle dinge. Hy is verknog aan die wêreld en wil deur wêreldse prestasies eer voor God verwerf. Hierdeur word hy ten diepste onvry. Die uiterlike mens egter weer, is 'n diensbare kneg en elkeen se onderdaan. In soverre die mens vry is, hoef hy niks te doen nie. In soverre hy 'n kneg is, moet hy allerlei doen. Juis omdat die innerlike mens vry is, kan hy as uiterlike mens soveel doen. Hy kan dus werklik in vryheid sy lewe aan die doen van die liefde wy. Trouens, die gelowige, die goeie boom, kan nie anders as om goeie vrugte op te lewer nie. Lewer iemand nie die goeie vrugte nie, is hy nie 'n goeie boom, 'n gelowige nie. Volgens Luther moet die goeie werke, die liefdesdiens op die medemens gerig wees, aangesien die mens nie net in sy liggaam nie, maar ook in die gemeenskap lewe. Goeie werke moet dus uitsluitlik daarop gerig wees om andere ten dienste en tot nut te wees. 'n Christen leef nie net vir homself nie, hy leef tot die voordeel van andere. Werke wat net op die eie voordeel gerig is, is volgens Luther nie Christelik nie. Die Christen moet vir andere dus tot 'n Christus word, sê Luther. 'n Christus is iemand wat andere vrywillig dien. Luther (WA 7, 38; my vertaling) kon sy traktaat daarom met die volgende woorde afsluit:

'n Christenmens leef nie in homself nie maar in Christus en sy naaste; in Christus deur die geloof, in sy naaste deur die liefde. Deur die geloof vaar hy bokant hom in God; vanuit God vaar hy weer onder homself deur die liefde en bly tog altyd in God en die Goddelike liefde...Kyk, dit is die regte, geestelike Christelike vryheid, wat die hart vry maak van alle sondes, wette en gebooie, wat alle ander vryheid oortref soos die hemel die aarde oortref.

(WA 7, 38; my vertaling)

Dieselfde kritiek wat deur Herbert Marcuse en Max Scheler (vgl Jüngel 1978:59-69) teenoor Luther uitgespreek is, kan ook deur ons kerk herhaal word, aangesien ons kerk tot hiertoe vryheid ook polities verstaan het. Die vraag wat aan Luther gestel word is, of sy vryheidsbegrip enige politieke relevansie het? Indien vryheid met die innerlike van die mens te make het, word die uiterlike dan nie aan die duiwel oorgelaat nie? Is die maatskaplike en politieke onvryhede dan nie vir die Christen van belang nie? Natuurlik is die uiterlike vryheid vir Luther ook van belang. Daar moet egter besef word wat Luther eintlik wou tuisbring. Sy bedoeling was om te ver- 
duidelik dat die mens nie deur die daad, ook nie die daad van selfverwesenliking, tot wesensvervulling kan kom nie. Dit is deur te hoor en te glo, dat die mens tot sy ware self kom. Die mens kan nie tot vervulling kom deur sy werke wat van verganklike aard is nie. Slegs deur in die sfeer van die onverganklike te kom, word ware vryheid ervaar, aangesien mens in hierdie sfeer met die waarheid ${ }^{3}$ en sodoende met God te make kry (Pannenberg 1958:251-257). Wie 'n-deur-die-daad-uitgebakleide politieke vryheid met Christelike vryheid wil identifiseer, konfronteer mense met leuens en dompel hulle in 'n maatskaplike onverantwoordelikheid. Jüngel (1978:94-95) het in hierdie verband die volgende wysheid uitgespreek:

Jede Theologie, die die geistliche Freiheit und Macht des Christen unmittelbar mit dessen weltlichen Lebensbezügen identifiziert, wird sich fragen lassen müssen, ob sie damit nicht paradoxerweise gerade die weltlichen Lebensbezüge christlich irrelevant werden läßt, weil jede unmittelbare Identifikation des geistlichen Anspruchs der libertas christiana mit weltlichen Ansprüchen diesen nur als maßlose Behauptung und hypertrophe Versicherung erscheinen lassen kann. Nur wenn die Behauptung der christlichen Freiheit nicht unmittelbar identisch gesetzt wird mit den gar nicht hoch genug zu schätzenden weltlichen Freiheitsbewegungen in allen Bereichen unseres irdischen Daseins, nur dann gibt es so etwas wie einen christlichen Beitrag zu den Freiheitsbewegungen, in denen sich das menschliche Leben auf allen Ebenen seines Daseins schon immer vorfindet, ohne doch den Fortschritten in ein freieres Leben eine eindeutige Überlegenheit über die schrecklichen Rückschritten in die Unfreiheit attestieren zu können.

(Jüngel 1978:94-95)

Mense wat innerlik vry is, mense wat vry is teenoor die kom en gaan van aardse vryhede, sal instaat wees om te doen wat die Here van hulle verwag, naamlik om in liefde met hulle medemens saam te lewe. Hierdie liefde sal die Christen ook daartoe bring om sy maatskaplike en politieke verantwoordelikhede te besef, sonder om in die dwaalgang te beland om te dink dat die Christelike vryheid wêreldlik realiseerbaar is (Pannenberg 1958:256-258). Hierdie liefde van die knegskap, laat ook nie ruimte vir die sonde van selfgesentreerdheid en selfgerigtheid, wat uitmond in 'n permanente selfbekommernis (Joest 1983:133) en daarom ongeloof nie. Die vrye liefde red mense daarvan om hulle lewe, hulle identiteit, ten alle koste te wil behou, aangesien hulle weet dat hulle dit juis dan sal verloor. Om hierdie redes pas geslote eredienste ook net nie by die vryheid en die liefde en by Markus 8:35 in nie. 


\subsubsection{Die kerk en die vryheidstryd van die volk}

Die kritiese vraag wat nou gevra moet word, is of die Reformatoriese vryheidsbegrip soos wat Luther dit uit die regverdigingsleer en die leer oor die verhouding tussen wet en evangelie ontwikkel het, nie ten opsigte van die konkrete werklikheid irrelevant en onbruikbaar is nie? Tweedens kan gevra word of hierdie vryheidsbegrip enige impak op ons kerk en die res van die Christendom sal hê, aangesien vryheid in ons kerk en veral in die ekumeniese teologie konkreet polities verstaan word.

Sekerlik het die kerk die verantwoordelikheid om humaniteit te bevorder. Aangesien humaniteit net binne 'n vryheidsruimte kan gedy, behoort die kerk ook'n kampvegter vir vryheid - veral die vryheid van sy eie lidmate - te wees. Die vraag is net: hoe kan die kerk die vryheid en humaniteit van sy lidmate bevorder? Ek (net soos andere in die kerk - vgl Van Wyk 1991:780) is van mening, dat die kerk in sy roeping sal misluk, wanneer hy 'n bepaalde maatskaplik-politieke gestalte as 'n voorwaarde vir vryheidservaring sal voorhou. Deur dit te doen, mislei jy die volk tot 'n utopistiese heilsverwagting. Jy moedig ' $n$ onbehaaglike werklikheidsbelewing aan en verskuif verantwoordelikheidsaanvaarding na die toekomstige ideale tydperk (kyk vir volledigheid Van Wyk 1991a). Die regmatigheid van die sogenaamde Lutherse twee-ryke-leer (wat die politieke gestalte van die regverdigingsleer is) is die klem wat op die wêreldlikheid van die wêreld geplaas word, met die bedoeling, dat 'n stuk wèreld nie met die Koninkryk verwar sal word nie. 'n Oneindige kringloop van teodiseekrisisse word ontketen wanneer 'n stuk politieke werklikheid direk aan die wil van God gekoppel word. Ons gaan juis in die volgende jare met die vraag na die geregtigheid van God worstel, aangesien ons die apartheidsbestel, wat nou ten gronde gaan, so nou aan die wil van God gekoppel het (kyk vir volledigheid Van Wyk 1987:14-69). Die vryheid van die volk sal beter gedien word, wanneer die kerk sy diens aan die volk vanaf die utopiese na die reg verskuif. Dit impliseer dat die kerk die stryd om aparte vryhede aan die politici moet oorlaat, sodat hy hom met volle oorgawe met menseregte besig kan hou. Ons kerk moet daarom nie meer in menseregte 'n vyand nie (Wolmarans [1962] 1978b), maar wel 'n vriend sien. Die kerk moet binne die ruimte van die haalbare en moontlike (Van Wyk 1991b:730742), die regte van sy lidmate help bevorder en verseker.

Die kerk sal daarmee rekening moet hou, mits daar dalk 'n suksesvolle blanke rewolusie kan plaasvind, dat ons kerk se lidmate in die toekoms nie deel van die magselite gaan wees nie. Ons gaan deel vorm van 'n polities onbelangrike minderheid. Binne hierdie situasie van politieke en maatskaplike irrelevansie, sal die kerk 'n relevante rol speel, wanneer hy sy profetiese taak aanvaar om voorspraak te maak vir reg en geregtigheid teenoor die swakkes van die samelewing. Op hierdie 
wyse sal ons kan voortgaan met ons 'bevrydingsteologie'. Ons sal binne ander omstandighede die vryheid van ons lidmate kan dien - maar dan 'n vryheid wat in die reg begrond is en met die liefde gevoed word (Pannenberg 1978b). As ons dit wil doen, sal ons moet toesien, dat ons nie met 'n regs- en morele agterstand begin, deur aan geslote eredienste vas te hou nie.

Ten spyte van alles wat nou gestel is, moet daar onthou word, dat die kerk se stryd vir reg en geregtigheid nie sy wesenlike en belangrikste taak is nie. Van Zyl (1942:61-62) het in 1942 gesê dat daar eers van ware nasionalisme binne die kerk sprake kan wees wanneer die kerk die volk met die volle waarheid van die Woord konfronteer en aan hom die sakramente bedien. Hiermee wou hy sekerlik sê dat die kerk polities relevant is wanneer hy die evangelie aan die volk bedien, aangesien die evangelie, die spreke oor en die nadenke oor die dade van God in Christus Jesus, polities uiters relevant is (Jüngel 1977:XVI). Die kerk kan die volk polities geen groter guns bewys, as om net kerk te wees nie. Die kerk bied die volk die meeste wanneer hy die seën van God oor hom uitspreek, aan hom die nagmaalsbeker en nagmaalsbord reik en sy kinders doop.

\subsection{Die liefdesgebod}

By 2.1.2.1 het ek die argument aangevoer dat ons kerk in die verlede, ten spyte van probleme daaraan verbonde, op 'n legitieme wyse met die liefdesgebod omgegaan het. Die insig, dat die prinsiep van die liefde nie onbemiddeld in die werklikheid gerealiseer kan word nie, sluit by die debat binne die etiek aan oor die skeppingsordeninge of die leer oor die 'institusies' (kyk bv Wendland 1971 en Honecker 1990: 291-313. Die skeppingordeninge, institusies of mandate (Bonhoeffer), naamlik die huwelik, familie, eiendom en staat is onvervangbare gegewendhede van hierdie lewe. Die moraal kan daarom ook slegs binne hierdie ordeninge gestalte aanneem. Die etiek moet daarom byvoorbeeld met die gesin- en familiestruktuur en die spesifieke staatsmodel van 'n samelewing rekening hou, indien hy eties invloed in so 'n samelewing wil uitoefen.

Ten spyte van ons vadere se regte etiese grondbeslissing, het hulle egter een teologiese keuse gemaak wat kerkhistories vreemd en selfs bedenklik is. Hulle het 'volk' en 'ras' tot teologies bruikbare 'skeppingsordeninge' verhef (kyk bv Wolmarans 1960:232). Dit is sekerlik nie uitgesluit, en 'n mens hoop werklikwaar dat dit so sal wees, dat daar in die toekoms tog groter realisme binne die ekumeniese wêreld oor die kultuur- en volksgebondenheid van die teologie sal kom. Tot dusver is daar egter weinig begrip en waardering vir ons teologiese maksels. Ek wil in hierdie verband net Karl Barth (wie ons graag as ons geestelike vader sien) se oordeel oor hierdie sake onder die aandag bring. Barth (KD III 4, 345-349) handel onder die 
opskrif Freiheit in der Gemeinschaft oor diegene wat na aan jou is en diegene wat ver van jou is. Hy onderskei tussen diegene wat deur gemeenskaplike biologiese erfgoed, gemeenskaplike taal en kultuur nă aan jou is en die res van die mensdom. Aangaande hierdie 'res' het Barth die volgende te sê: Seker is daar mentaliteitsverskille tussen mense, maar hierdie verskille is net relatief. Uit hulle kan daar nie 'n eksklusiewe afgrensing tusssen mense van 'n ander velkleur of taalgroep afgelei word nie. Die eksklusiewe binding van 'n Christen aan sy volk, ras en kultuurkring is 'n ketterse uitvinding, aangesien hierdie kettery 'n volksgod in die plek van God, die Vader van alle mense, plaas. Barth herinner dan daaraan dat die ontdekking van die 'volk' as 'n 'skeppingsordening' 'n teologiese nuwigheid is (hiermee stem Pont 1991:783-786 saam). Hy wys daarop, dat die groot teologiese naslaanwerke soos die $R G G$ en die Protestantische Realenzyklopädie en selfs die etici van die Ritschl-skool, voor 1914, nie die term 'volk' geken het nie. Natuurlik het die filosowe van die Romantiek, met Herder aan die voorpunt, met hierdie term filosofie gemaak, maar dit was eers mense soos Paul Althaus wat teologies met hierdie term binne hulle 'geskiedenisideologie' gewerk het. Vir Barth was daar te veel probleme rondom die 'ordeningsteologie' en daarom het hy, beslis na my mening te eensydig, sy etiek net aan die personaliteit van die mens gebind en alle institusionele gegewendhede geïgnoreer. Die rede hoekom Barth (KD III 4, 31) hierdie ordeninge en gegewendhede wel kon herken, maar nie daaraan teologiese status en gehalte wou gee nie is die volgende:

Wenn Gott und Mensch sich begegnen, so wie es in Gottes Wort offenbar ist, dann werden bestimmte Bereiche und Verhältnisse sichtbar, in denen diese Begegnung stattfindet...Man könnte diese (Bereiche und Verhältnisse) wohl auch Ordnungen nennen. Aber das Mißverstăndniss, als ob sie auch so etwas wie Gesetze, Vorschriften, Imperative seien, müßte dann ganz ausgeschaltet bleiben. Sie sind Bezirke, in welchen Gott gebietet und in welchen der Mensch gehorsam oder ungehorsam ist, nicht aber Gesetze, gemäß welchen Gott gebietet und der Mensch gut oder böse handelt.

(Barth $K D$ III 4, 31)

Ons sal sekerlik nie met Barth geheel en al oor sy waardering van die 'volksgedagte' vir die teologie kan saamstem nie (kyk Breytenbach 1979 en van Aarde 1979). Dit is egter ' $n$ feit dat wanneer daar aan die etiese grondbeslissing van ons vadere vasgehou wil word, ons kerk se standpunt en houding ten opsigte van volkereverhoudings en geslote eredienste nie dieselfde kan bly nie, aangesien ons lewenswerklikheid geweldig baie sedert die Groot Trek verander het. Die swart bevolking as geheel, is nie meer die onderontwikkelde, barbaarse massa wat die Voortrekkers 
geken het nie. Taal, veral as aan die bruin boere gedink word, is nie meer die skeidingsfaktor van die verlede nie. Die ekonomiese-, beroeps- en demografiese werklikhede van talle van ons lidmate, laat 'n gedwonge skeiding ten alle koste net nie meer toe nie. Wie nie van die veranderde werklikheid van ons lidmate kennis wil neem nie, is eenvoudig aan sy eie teologiese tradisie ontrou.

Liefde as gun aan elkeen sy eie vrye ruimte en hou hom ook in sy eie ruimte (De Wet \& Pont 1964:134-136) is vandag in talle gemeentes net nie meer houdbaar nie. Trouens - hierdie moraal word as liefdeloosheid gesien. Liefdeloos, aangesien swartmense dit as 'n belediging en krenking van hulle menswees ervaar om toegang tot 'n 'wit kerk' geweier te word. Liefdeloos, aangesien daar in die wegwys van mense by 'n kerkdeur, niks blyk van die Christelike nederigheid, vriendelikheid en gasvryheid nie. Wanneer 'n etiket van liefdeloosheid om die nek van 'n kerk gehang word, het hy 'n geweldige legitimiteits- en geloofwaardigheidskrisis in hierdie wêreld ontwikkel. Erger nog! In sy posisie voor God moet hy net met angs en bewing staan; want hoe gaan so 'n kerk die eindoordeel oor die werke tegemoet? Ons sal teologies oneerlik wees, deur ons net met die eindoordeel teenoor ons vyande te troos (Van Wyk 1993a:5-6), maar ons self nie daardeur te laat aanspreek nie. Ons sal vir ons nuwe omstandighede 'n nuwe teorie oor die liefde moet uitwerk. Dit is 'n saak wat teologies té belangrik is om maar net te ignoreer.

In aansluiting by Luther se vryheidsbegrip is daar tog enkele aspekte van die Christelike liefde wat kortliks vermelding verdien. Luther se insig dat die Christelike liefde met knegskap, diensbaarheid en onderdanigheid te make het, het verreikende konsekwensies. Die vrye Christelike liefde het daarom vanuit hierdie perspektief nie soseer met heerskappy en magstryd te make nie, maar eerder met gemeenskap (vgl Moltmann 1991:130-132). Om hierdie rede is my medemens, ook die vreemde een, nie 'n beperking van my vryheid nie, maar eerder die verlenging van my vryheid (Moltmann 1980:233). Ten spyte daarvan, dat ek (1987) Moltmann se teologie as 'n geslote ideologiese denksisteem verwerp, sal 'n mens moet toegee, dat daar groot waarheid in hierdie woorde steek (Moltmann 1979:91):

Wer frei ist, ist freundlich, geneigt, offen, erfreulich und liebend. Wir finden dieses Verständnis noch im Ausdruck 'gastfrei'. Wer gastfrei ist, beherrscht keine Gäste, er ist auch nicht ohne Gäste; er ist zur Gemeinschaft mit Fremden fähig und wird ihr Freund. Freiheit als Herrschaft zerstört Gemeinschaft.

(Moltmann 1979:91)

Vryheid as diensbare gemeenskap met ander gelowiges laat daarom so iets soos geslote eredienste net eenvoudig nie toe nie. Omgekeerd sal gelowiges buite ons kring kwalik tot 'n ander gevolgtrekking kan kom, as dat ons as Hervormers mense is wat in onvrye liefdeloosheid vasgevang is. 


\section{GESLOTE EREDIENSTE IN DIE NUWE SUID-AFRIKA?}

\subsection{Argumente ten gunste van die behoud van Artikel III en geslote eredienste} Artikel III, aparte volkskerke en geslote eredienste is emosionele sake. Dit het met mense se selfverstaan, hulle identiteit en hulle hoop te make. Dit is sake wat met die 'belydenisse van die hart' te make het. Om hierdie redes sal dogmatiese argumente en historiese werklikhede mense nie noodwendig aanspreek nie. Of, al sou dit mense aanspreek, sal dit nie dieselfde krag hê as die simbole wat mense se lewens ten diepste beïnvloed en bepaal nie. Juis omdat Artikel III as 'n simbool funksioneer sal dit vir talle lidmate onaanvaarbaar wees dat Artikel III geskrap word en dat die eredienste oopgestel word. Die volgende argumente sou daarom ten gunste van die behoud van die status quo geopper kon word:

\subsubsection{Simbool van vryheid}

Daar sou geargumenteer kon word, dat Artikel III en geslote eredienste as 'n simbool en dan wel as 'n simbool van Afrikanervryheid verstaan moet word. Om hierdie rede moet hierdie ordereëlings ten alle koste behou word. Die Hervormde Kerk as volkskerk, as draer van die Voortrekkerideale mag hierdie reëlings daarom nie skrap nie. Die Hervormde Kerk moet aan sy historiese basis getrou bly en mag dit nie verloën nie. Juis in hierdie tyd waar die Afrikaner se vryheid bedreig word, moet hierdie simbool van vryheidstrewe lewend en wakker gehou word. Die skrapping van Artikel III en die oopstel van die eredienste sou neerkom op dislojaliteit teenoor die volk.

\subsubsection{Simbool van weerstand}

Daar sou ook geredeneer kon word dat Artikel III nog altyd as 'n simbool van weerstand teen onderwerping gefunksioneer het en dat hy om hierdie rede juis in hierdie tyd behou moet word. Hierdie artikel as simbool van weerstand teen vreemdbestemming kan aan die Afrikaner in sy krisisuur moed en hoop gee. Die behoud van Artikel III, sou 'n bewys wees van die solidariteit van die Hervormde Kerk met die vryheidstryd van die volk.

\subsubsection{Simbool van rassestryd}

Dit moet maar erken word dat Artikel III en die reëling van geslote eredienste, vir tảlle lidmate as simbool van 'n bepaalde rassebewussyn geld. Hierdie ordereëlings geld vir talle blanke Afrikaners as 'n stuk godsdienstige legitimasie vir hulle stryd om uniekheid, suiwerheid, verhewendheid en heerskappy. Juis omdat hierdie ordereëlings 'n belangrike simbool in die rassestryd is, sal talle lidmate selfs die kerk verlaat indien hierdie reëlings afgeskaf sou word. 


\subsubsection{Simbool van 'verlore paradys'}

In die 'nuwe Suid-Afrika' sal die neiging binne die tradisionele blanke kerke waarskynlik wees, om 'n 'veilige hawe' vir die blankes te skep. Die rol van hierdie kerke sal na alle waarskynlikheid wees om blankes te help om in die 'nuwe SuidAfrika' te oorleef en nie om hulle te help om in die nuwe situasie te leef nie. Die kerk sal dus vir die Afrikaner 'n simbool van die goeie ou tyd wees. Op simboliese wyse sal daar 'n stukkie van die 'verlore paradys' ervaar kan word. 'n Afgesonderde geslote gemeenskap net vir blankes, sal 'n belangrike terapeutiese funksie in die toekoms vervul. Om hierdie rede sal mense moeilik van Artikel III wil afstand doen, aangesien dit hulle vertroostingsvesting in gevaar kan stel.

\subsection{Argumente teen die behoud van Artikel III en geslote eredienste}

\subsubsection{Die veranderinge in die sosiale werklikheid: Die botsing tussen prinsiep en werklikheid}

Diegene wat vir die behoud van Artikel III pleit, is nie getrou aan die tradisionele teologiese argumentasiewyse van ons kerk nie. Die kerk was deur sy geskiedenis gekant teen die vashou aan 'n prinsiep los van die werklikheidsomstandighede. Die eietydse verdedigers van Artikel III maak hulle juis hieraan skuldig. Hulle wil die prinsiep ten alle koste laat geld, sonder om met die werklikhede van hierdie land rekening te hou.

Ons werklikhede - sosiologies, polities, staatkundig, demografies, volkekundig, sosiaal-psigologies - het die laaste aantal jare dramaties verander. Alles wat daartoe bygedra het om van Artikel III 'n verstaanbare en aanvaarbare kerklike reëling te maak het verdwyn. Die polities-maatskaplike ondersteuningsbasis van hierdie artikel het verkrummel. Alle wetgewing wat hierdie artikel aanvaarbaar en duldbaar gemaak het, is afgeskaf. Die politiek-maatskaplike omstandighede het alreeds in so 'n mate verander, dat die kerk nie meer met sy tradisionele ordereëlings deel van die openbare lewe kan bly nie. Indien die kerk sy predikante aan 'n universiteit wil oplei, sal daardie fakulteit 'n oop fakulteit moet wees, aangesien daar nie 'n geslote fakulteit aan 'n oop universiteit kan wees nie. Indien die kerk sy maatskaplike dienste met behulp van staatsfondse wil voortsit, sal hy alle diskriminasie op grond van ras en kleur moet afskaf, aangesien die staat dit vereis.

Die praktiese situasie gaan veroorsaak dat die kerk, met sy tradisionele houding, nie sonder verleentheid en konflik sal kan funksioneer nie. Om enkele voorbeelde te noem: 
- Talle gemeentes gaan met die onafwendbaarheid te make kry dat daar per geleentheid anderskleuriges hulle eredienste sal wil bywoon. Studentegemeentes wat deel is van 'n oop universiteit met oop koshuise en 'n geïntegreerde sosiale struktuur sal hulle deure nie vir bruin en swart studente gesluit kan hou nie. Doen hulle dit, sal hulle hul voorregte aan die betrokke universiteit verloor.

- 'n Weermaggemeente sal tog sekerlik nie 'n swart soldaat, wat 'n lidmaat van die HKSA is, die deur kan wys nie. Sou dit gedoen word, sal die kerk se voortgesette deelname aan die kapelaansdienste in gevaar gestel word.

- Die kerk se lidmate kan ook nie meer van geïntegreerde godsdienstige samekomste verhinder word nie. In hospitale gaan niks en niemand 'n swart predikant verhinder om in 'n saal waar 'n Hervormer mag lê, te bid nie.

- Die belangrikste argument is sekerlik die volgende: Daar kan min twyfel daaroor bestaan, dat talle van ons lidmate ' $n$ keuse sal moet maak tussen hulle beroep en hulle kerk. Veral diegene wat in staatsdepartemente en semi-staatsinstellings werk, sal moeilik hulle posisies kan behou, indien hulle lidmate van 'n kerk is wat rassediskrimenasie in sy midde toelaat.

Artikel III en alles wat daarmee saamgaan, is dus met die werklikheid in botsing. Dit is daarmee in botsing, hoofsaaklik as gevolg van die verlies van absolute politieke mag van die Afrikaner, die gelykstelling tussen alle mense en die opkoms van menseregte.

\subsubsection{Die verlies van absolute politieke mag}

Niemand kan op hierdie tydstip naastenby 'n voorspelling waag oor wat in die toekoms op politieke terrein mag gebeur nie. Een feit sal na alle waarskynlikheid nie verander nie en dit is dat die Afrikaner nie meer oor absolute politieke mag (oor die hele Suid-Afrika) beskik nie. Wat ons ookal konstitusioneel in die vooruitsig mag stel, dit sal nie deur ons alleen verwesenlik kan word nie. Selfs nie eers 'n aparte volkstaat sal eensydig afgekondig kan word nie. Daarom sal dit onwaarskynlik wees dat ons weer 'n sosiaal-politieke ondersteuningsisteem vir die kerk se apartheidsideale sal kan opbou. Indien die kerk met sy apartheidsdrome wil voortgaan, moet hy net onthou dat hy nie op die onvoorwaardelike steun van die politici en nog minder van die owerhede kan staatmaak nie.

\subsubsection{Gelykstelling tussen swart en wit}

Dit sal toegegee moet word, dat die Afrikaner, minstens voorlopig, die stryd teen gelykstelling verloor het. Die wêreldgeskiedenis het ons (soos by punt 3.2 aangedui) ingehaal. 
In Suid-Afrika word die gedagte van algemene stemreg vir almal deurgevoer. Dit lyk of die Afrikaner hierdie idee nie ongedaan sal kan maak nie, en met hierdie gedagte sal moet saamleef. Wat ookal polities gaan gebeur, ons sal die gelykstellingsgedagte, in die politieke sin, nie geheel en al kan ontkom nie. Om hierdie rede het dit eintlik geen sin om 'n artikel in die Kerkwet te behou, wat histories agtergehaal is nie.

Sommiges mag nou meen dat die kerk se tradisionele standpunt in sake gelykstelling of vermenging juis as protesnota behou moet word, maar die vraag is net: teen watter koste? Wat sal die konsekwensies wees indien in 'n hof bewys kan word dat so ' $n$ artikel met die handves van fundamentele regte in botsing is?

'n Tweede aspek van die nie-gelykstellingsgedagte is ook deur die historiese ontwikkelinge ingehaal. Die swartman (of minstens ' $n$ groot gedeelte van die swart bevolking) is eenvoudig nie meer die swarte van die $17 \mathrm{e}$ en $18 \mathrm{e}$ eeue nie. Die argumente wat voorheen ten opsigte van die 'gevare van vermenging' geopper is, is nie sondermeer vandag nog geldig nie. Veral ten opsigte van die 'kleurlinge' geld die ou argumente, soos die taalargumente (vgl De Wet \& Pont 1964:121-127) net nie meer nie.

Waarvoor ons vandag sal moet ligloop, is dat ons nie met dieselfde sendingargumente as die London Missionary Society voor die dag kom nie. Indien ons Christenskap vandag van 'n bepaalde kulturele binding afhanklik wil maak, verlaag ons ook die sending tot 'n stuk kultuuroordrag - of beter gestel- tot 'n stuk kultuurbewaring. Indien ons meen, dat Christenskap slegs binne 'n bepaalde kultuurverband moontlik is, voer ons dieselfde argument as die Engelse sendelinge.

Wat wel houdbaar en verdedigbaar is, is die kultuurgebondenheid van godsdiens. Kultuurgebonde godsdiensuitlewing wat nie-diskriminerend en op die basis van vrye assosiasie beoefen word, sal selfs deur ' $n$ handves van fundamentele regte beskerm word.

\subsubsection{Menseregte}

Die deurslaggewende rede vir die skrapping van Artikel III en die oopstel van die eredienste, is in die wete begrond, dat hierdie ordereëlings met 'n handves van fundamentele regte, wat diskriminasie op grond van ras en kleur verbied, in stryd gaan wees. Net soos in die gevalle Zimbabwe en Namibië sal ons geen ander keuse hê as om hierdie ordereëlings te skrap nie.

Ons moet in 'menseregte' nie net ' $n$ vyand sien nie. 'Menseregte' gaan aan ons juis die reg gee om ons taal en kultuur ook in die 'nuwe Suid-Afrika' uit te lewe en te beskerm. Al waarvan ons dus afstand sal moet doen, is diskriminasie op grond 
van ras en kleur. Dit kan ons gerus maar doen in die wete dat bitter min in ons kerklike lewe sal verander - juis omdat godsdiens so 'n sterk kultuurgebonde saak is - of is ons dalk nie daarvan oortuig nie?

\subsubsection{Samewerking op ekumeniese gebied}

In ' $n$ 'nuwe Suid-Afrika' sal ons gedwing word tot groter ekumeniese samewerking. Alleenlik in bondgenootskap met ander kerke, sal ons invloed op die owerhede kan uitoefen om die Christelike perspektiewe te respekteer. Ander kerke sal net eenvoudig nie met ons wil saamwerk, indien ons nog steeds as 'n rassistiese kerk gebrandmerk word nie. Indien ons enige invloed in die sogenaamde 'nuwe SuidAfrika' wil uitoefen, sal ons van Artikel III en geslote eredienste moet ontslae raak.

\subsubsection{In stryd met die evangelie}

Ten spyte van al die deernis en begrip wat ons vir ons voorgeslagte mag hê, kan ons net nie anders, as om te besef dat ons kerk se ordereëlings met Skrif en Belydenis in stryd is nie. Al is hierdie sake praktiese reëlings, wat met 'n beleid en nie met 'n beginsel te make het nie, moet dit nogtans met Skrif en Belydenis in lyn wees. Hiervan kon ons ander kerke nog nie oortuig nie. Trouens, hulle bly daarvan oortuig, dat ons met 'kettery' besig is. Om hierdie rede sal ons emstig moet herbesin, indien ons 'n Reformatoriese kerk wil bly!

\section{KONKLUSIE}

Die Algemene Kerkvergadering sal nie 'n maklike taak hè om oor oop eredienste te besluit nie. Aan die een kant kan die kerk nie anders as om af te sien van die praktyk om die kerk se eredienste vir anderskleuriges gesluit te hou nie. So 'n praktyk is met die evangelie en met die gedagte van die 'menseregte' in stryd. Dit is dogmaties en eties onverdedigbaar. Aan die ander kant het hierdie pratyk soveel met die tradisie van die kerk, die identiteit van die volk en die hoop van talle mense te make, dat daar nie te maklik ' $n$ besluit geneem sal kan word nie. Dit is op hierdie stadium uiters moeilik om 'n voorspelling te waag oor wat op politieke terrein die volgende twee jaar gaan gebeur. Die politieke klimaat gaan 'n baie besliste invloed op die kerk se besluit uitoefen. Dit sal nie help om te sê dat hierdie saak alleen op dogmatiese en etiese vlak beslis moet word nie. Artikel III en geslote eredienste het in die verlede ten diepste met politiek te make gehad. Ook die afskaffing al dan nie gaan met politiek te make hê - of ons dit nou wil weet of nie. Ek is tog van mening dat wat ookal binne die afsienbare toekoms op politieke gebied mag gebeur, die kerk en die volk nie van die epogveranderende tendense op wêreldhistoriese vlak sal ontkom nie. Om hierdie rede het en gaan die geskiedenis ons inhaal. Ons 
beginsels en ons ideale is alreeds en gaan nog verder met die werklikheid in botsing kom. Dit sal daarom 'n historiese noodwendigheid wees, dat ons vroeër of later, net soos in die gevalle Zimbabwe en Namibië, hierdie ordereëlings sal moet skrap - hoe teësinnig ook al.

\section{ENDNOTE}

1. Hierdie geskiedenisvisie het niks met Arminianisme te make, soos 'n spreker tydens die bespreking van hierdie voordrag op die Predikantevergadering van die Nederduitsch Hervormde Kerk van Afrika in September 1993 aangevoer het nie. Natuurlik word daar ruimte vir God se ingrype gelaat. Natuurlik word hier nie beweer dat die geskiedenis 'n deterministiese proses is nie. Wat ongelukkig binne ons kerklike kring nie toegegee wil word nie, is dat subjektiewe, historiesbegrensde ideale, nie met die wil van God identies is nie.

2. Die enigste grootskaalse verandering, is dat talle lidmate die kerk verlaat het. Net enkelinge uit ander bevolkingsgroepe het na die Nederduitse Gereformeerde Kerk oorgegaan.

3. In 'n resente filosofiese werk oor die vryheid (Baruzzi 1993) word die klem ook weer gelê op die onlosmaaklike samehang van vryheid en waarheid - en dan waarheid oor ons posisie in die huidige wêreld.

\section{Literatuurverwysings}

Barth, K 1951. Kirchliche Dogmatik III, 4. Zürich: Zollikon.

Baruzzi, A 1993. Die Zukunft der Freiheit. Darmstadt: Wissenschaftliche Buchgesellschaft.

Botes, H J 1991. Kerk en volk in die bedeling na 1900. HTS 47, 800-809.

Breytenbach, A P B 1979. Die waardering van die volkereverskeidenheid in die Ou Testament, in Van Wyk 1979:169-174.

Dreyer, J [1962] 1978. Belydenis en beleid, in Van Wyk 1978:72-75.

Hamm, B 1983. Martin Luthers Entdeckung der evangelischen Freiheit. ZThK 80, 50-68.

Honecker, M 1990. Einführung in die theologische Ethik: Grundlagen und Grundbegriffe. Berlin: De Gruyter.

Joest, W 1983. Die Freiheit in Luthers Verständnis des Menschen. KuD 29, 127 137.

Jüngel, E 1977. Gott als Geheimnis der Welt: Zur Begründung der Theologie des Gekreuzigten im Streit zwischen Theismus und Atheismus. Tübingen: Mohr.

- 1978. Zur Freiheit eines Christenmenschen: Eine Erinnenung an Luthers Schrift. München: Kaiser. 
Jüngel, E 1980. Die Freiheit der Theologie, in Jüngel, E, Theologische Erörterungen $I I, 11-36$. München: Kaiser.

Kerk en Wêreld 2000 1985. Pretoria: Kital.

Kinghorn, J (red) 1986. Die NG Kerk en apartheid. Johannesburg: Macmillan.

Kommissie van die Algemene Kerkvergadering 1973. Herderlike Skrywe van die Algemene Kerkvergadering van die Nederduitsch Hervormde Kerk van Afrika aan die lidmate van die kerk oor sy opvatting met betrekking tot volkereverhoudings in die Republiek van Suid-Afrika, in Van Wyk 1978:258-272.

Labuschagne, J P 1991. 'Kerk' en 'volk' uit die hoek van moderne samelewingsteologieë. HTS 47, 810-824.

Luther, $M$ 1520. Von der Freiheit eines Christenmenschen. $W A$ 7,20-38 = Luther Dentsch. Hrsg K Aland [1991]. Bd 2, 251-274. Göttingen: Vandenhoeck. (UTB 1656.)

Luther, M 1883vv. WA = Kritische Gesamtausgabe. (Weimarer Ausgabe).

Moltmann, J 1977. Theologie der Hoffnung. München: Kaiser.

- 1979. Menschenwürde, Recht und Freiheit. Stuttgart: Kreuz.

- 1980. Trinität und Reich Gottes: Zur Gotteslehre. München: Kaiser.

- 1988. Was ist heute Theologie? Freiburg: Herder.

- 1991. Der Geist des Lebens: Eine ganzheitliche Pneumatologie. München: Kaiser.

Oosthuizen, A J G [1960] 1978b. Ons kerk, in Van Wyk 1978:31-34.

Pannenberg, W 1958. Christlicher Glaube und menschliche Freiheit. KuD 4, 251 280.

- 1973. Wissenschafistheorie und Theologie. Frankfurt: Suhrkamp.

- 1978a. Gottesgedanke und menschliche Freiheit. Göttingen: Vandenhoeck.

- 1978b. Christliche Rechtsbegründung, in Hertz, A, et al (Hrsg), Handbuch der christlichen Ethik. Band 2, 319-338. Freiburg: Herder.

- 1981. Die theokratische Alternative, in Pannenberg, W, Fonschritt ohne Maß?, 235-251. München: Piper.

- 1983. Anthropologie in theologischer Perpektive. Göttingen: Vandenhoeck.

- 1986. Heiligung und politische Ethik, in Pannenberg, W, Christliche Spiritualität, 59-81. Göttingen: Vandenhoeck. (KVR 1519.)

- 1988. Systematische Theologie, Band I. Göttingen: Vandenhoeck.

Pont, A D 1969. Kerk en volk. 'n Bespreking na aanleiding van die Algemene Kerkvergadering van Februarie 1888. HTS 25/3 \& 4, 202-218.

- [1959] 1978. Artikel III van die kerkwet kerkregtelik gesien, in Van Wyk 1978, 101-109. 
Pont, A D 1991. Die verhouding 'kerk en volk' in die jare 1835-1900 in die Oorvaalse: 'n Terreinverkkenning. HTS 47, 783-799.

Rendtorff, T 1978. Die christliche Freiheit als Orientierungsbegriff der gegenwärtigen christlichen Ethik, in Hertz, A et al (Hrsg), Handbuch der christlichen Ethik. Band 1, 378-388. Freiburg: Herder.

- 1986. Der Freiheitsbegriff als Ortsbestimmung neuzeitlicher Theologie am Beispiel der Kirchlichen Dogmatik Karl Barths, in Rendtorff, T, Gottes $\mathrm{Zu}$ kunft - Zukunft der Welt. Fetschrift für J Moltmann zum 60. Geburtstag. München: Kaiser.

Steenkamp, J J 1989. Artikel III bepaal erediensbywoning sowel as lidmaatskap. Leer- en Lewenskwessies in Suid-Afrika 12, 26-64.

Tönnies, F 1988. Gemeinschaft und Gesellschaft. Darmstadt: Wissenschaftliche Buchgesellschaft.

Van Aarde, A 1979. Volkereverskeidenheid en die Nuwe Testament, in Van Wyk 1979:175-179.

Van 't Spijker, W 1990 . De kerk bij Calvijn: Theocratie, in Van 't Spijker, W et al (red), De Kerk: Wezen, weg en werk van de kerk naar reformatorische opvatting, 143-162. Kampen: De Groot Goudriaan.

Van Wyk, D J C (red) 1978. Stemme uit die verlede, I: Volkereverhoudings in SuidAfrika. Pretoria: HAUM.

- (red) 1979. Lidmaatskap in die Nederduitsch Hervormde Kerk van Afrika: Studie oor Artikel III van die Kerkwet. Ongepubliseerde publikasie.

- 1985. Artikel III van die Kerkwet van die Nederduitsch Hervormde Kerk van Afrika: 'n Verantwoording. Pretoria: Kital.

- 1991. Kerk en volk. HTS 47,768-782.

Van Wyk, I W C 1985. 'n Krisis van die Skrifgesag: Die krisis van godsdiensverstaan en -belewenis? Die Hervormer, Desember, bl 16.

- 1987. Das Theodizeeproblem als Orienterungspunkt der kirchenpolitischen und theologischen Streitfragen: Eine Auseinandersetzung mit Jürgen Moltmann. Ongepubliseerde DD-proefskrif, Universiteit van Pretoria.

- 1990. Hou op om God te gebruik vir ons denkbeelde oor samelewing. Die Hervormer, 1 November, bl 5 en 6.

- 1991a. Die Christen in die veranderende Suid-Afrika, in Veranderende SuidAfrika: 'n Uitdaging aan Christene, 70-74. Bloemfontein: Credo.

- 1991b. Protesoptogte en die rol van die Nederduitsch Hervormde Kerk. HTS 47, 716-745. 
Van Wyk, I W C 1993. Die eindoordeel: Monster of geraamte? Die Hervormer 15 Februarie, bl 5 en 6.

Van Zyl, F J 1942. Ons kerk en ons volk. Die Almanak 26, 58-62. Pretoria: NHW Pers.

Wendland, H-D 1971. Einführung in die Sozialethik. Berlin: De Gruyter.

Wolmarans, H P 1960. Artikel III van die Kerkwet van die Nederduitsch Hervormde Kerk van Afrika. HTS 16, 231-239.

- [1953] 1978a. Die Christelike plig van die Blankes teenoor die Nie-Blankes in Suid-Afrika, in Van Wyk 1978:22-27.

- [1962] 1978b. Menswaardigheid en menslike regte na aanleiding van die Skrif, in Van Wyk 1978:85-93. 